\title{
The Moderating Effect Of Corporate Reputation Management On Psychoslogical Contract Violation And Counterproductive Work Behaviour
}

\author{
Ömer Okan FETTAHLIOĞLU * \\ * Kahramanmaraş Sütçü İmam Üniversitesi İİBF İşletme Bölümü \\ E-mail: ofettahlioglu@ksu.edu.tr
}

Copyright (C) 2015 Yrd.Doç.Dr.Ömer Okan FETTAHLIOĞLU. This is an open access article distributed under the Eurasian Academy of Sciences License, which permits unrestricted use, distribution, and reproduction in any medium, provided the original work is properly cited.

\begin{abstract}
In recent years organizations have difficulty in coping with management behaviour such as psychological contract violation and counter-productive work behaviour. Researchers have found that a positive relationship between the occurrence of psychological contract violation and the arise of counter-productive work behaviour exists. However there is no study to these terms with regard to corporate reputation management. In this study hypotheses on the relationship between psychological contract violation and counter-productive work behaviour and the question whether a regulatory impact of corporate reputation management on this relationship exists, are tested. Data from a study on 272 employees working in a steel cookware production firm indicates a positive relationship between psychological contract violation and counter-productive work behaviour; it also supports that working on corporate reputation management shows a moderating effect on this relationship.
\end{abstract}

Keywords: Psychoslogical Contract Violation, Counterproductive Work Behaviour, Corporate Reputation Management, Moderating Effect

JEL-Clasification: M12, M14, L25, L20, M51

\section{Kurumsal İtibar Yönetiminin, Psikolojik Sözleşme İhlali ile Üretkenlik Karşıtı Davranışlar İlişskisinde Düzenleyici Etkisi}

\section{ÖZET}

Psikolojik sözleşme ihlali ve üretkenlik dışı davranışlar son yıllarda örgütlerin başa çıkmakta zorlandığı örgütsel davranış sorunları arasındadır. Araştırmacılar tarafından, psikolojik sözleşme ihlali algısının ortaya çıkması ile üretkenlik dışı davranışların sergilenmesi arasında olumlu bir ilişkinin olduğu ortaya konulmuştur. Ancak bu kavramları, kurumsal itibar yönetimi açısından ele alan bir çalışma söz konusu değildir. Bu çalışmada, psikolojik sözleşme ihlali ile üretkenlik dışı davranışlar arasındaki ilişkiler ve bu ilişkide kurumsal itibar yönetiminin düzenleyici etkisinin olup olmadığına yönelik hipotezler test edilmiştir. Çelik tencere imalatı yapan bir firmada çalışan 272 personel üzerinde yapılan çalışmanın bulguları; psikolojik sözleşme ihlali ile üretkenlik dışı davranışlar arasında pozitif yönde olumlu bir ilişki olduğunu, kurumsal itibar yönetimine yönelik çalışmaların da bu ilişkide düzenleyici olduğunu destekler niteliktedir. 
Anahtar Kelimeler: Psikolojik Sözleşme İhlali, Üretkenlik Dışı Davranışlar, Kurumsal İtibar Yönetimi, Düzenleyici Etki.

\section{GIRISS}

Çalışma hayatının en önemli rekabet unsurlarından biri de insan faktörüdür. Bilgi çağında işletmelerin rekabet gücü sadece maddi güçlerden değil, çalışanların nitelikleri ve sahip oldukları entelektüel birikimlerden kaynaklanmaktadır (Baybora, 2011:118). Bu nedenle son dönemlerde, çalışanlar ile işletme sahip veya yöneticileri arasında ortaya çıkan etkileşim üzerine çalışmaların yoğunlaştığı görülebilmektedir. Söz konusu etkileşim sonucunda işletmeler, olumlu veya olumsuz sonuçlar ile karşı karşıya kalabilmektedir. Etkileşimin olumlu sonuçlar ortaya çıkarması için de, olumsuzluk yaratıcı faktörlerin ortadan kaldırılması gerekmektedir. Son yirmi yıldır işletme hayatına olumsuz yönde etki ettiği düşünülen iki kavramdan bahsedilir olmuştur. Bu kavramlar "psikolojik sözleşme ihlali" ve "üretkenlik dış1 davranışlar"dır.

Çalışanlar ile işletme sahipleri arasında, karşılıklı olarak yerine getirileceği vaat edilen sözleri tanımlamak için psikolojik sözleşme kavramı kullanılmaktadır. Taraflardan herhangi biri psikolojik sözleşmede yer alan unsurlardan bazılarını ihlal ettiğinde, bireysel bazda başlayan sorunlar, işletmenin geneline yayılmakta ve önlenemez bir hal almaktadır. Örneğin çalıştıkları ortamdan hoşnut olmayan çalışanlarda, işverenlere karşı güvensizlik ve iş değiştirme isteği duygusu ortaya çıkmaktadır (Saylı ve Uğurlu, 2007:85). Bu durum, diğer çalışanlar üzerinde de olumsuz etkiler ortaya çıkarabilmektedir. Bu durumda, yöneticilere düşen asıl görev, psikolojik sözleşmenin hangi unsurları kapsadığını belirlemek ve hangi durumlarda ihlal edildiği algısının ortaya çıkabileceğini tespit ederek, buna yönelik önlemler almaktır.

İş ortamında huzursuz olan çalışanlar, çalıştıkları işletmenin iş akışını engelleyici davranışlar sergileyebilmektedir. Hatta bu davranışlar işletmenin verimliliğini azaltacak bilinçli davranışlar haline gelebilmektedir. Bu tür davranışları açıklamak için de, işletme literatüründe "üretkenlik dışı davranışlar” kavramı kullanılmaktadır. Üretkenlik dışı davranışlar, işletmenin genel ve özel amaçlarına ulaşmasında engelleyici bir unsur olarak karşımıza çıkabilmektedir. $\mathrm{Bu}$ davranışların tespit edilmesi ve daha ortaya çıkmadan engellenmesine yönelik önlemlerin alınması, işletmenin amaçlarına ulaşmasında önemli bir unsurdur.

İşletmelerin dış müşterilerini memnun etmesi için, öncelikle iç müşterilerini (çalışanlarını) memnun etmesi gerekmektedir. Psikolojik sözleşme ihlali ve üretkenlik diş1 davranışlar, çalışanların memnuniyet derecesinin az olduğunu gösteren unsurlardır. Bu durum işletmenin kurumsal itibar olgusuna da olumsuz bir şekilde yansımaktadır. Kurumsal itibar yönetimi ile işletmeler, dış müşterilerine olduğu kadar, çalışanlarına da olumlu bir imaj yaratabilme amacını hedeflemektedir.

Yapılan araştırmalar, örgüt çalışanlarının kurumsal itibarı, kurumsal itibarın da çalışanları etkilediğini göstermektedir (Dörtok, 2004:10). Yetenekli çalışanları elde tutmak için, onları motive edebilmek ve güven ortamı oluşturmak gerekir. İşgörenlerin, kendisini çalıştığı kurumla özdeşleştirmesi, kurumun temel değerlerini benimsenmesi, istenen şekilde davranış sergilemeleri, kurumsal itibarın oluşmasında önemli rol oynamaktadır (Gotsi ve Wilson, 2001:99). 
$\mathrm{Bu}$ çalışmanın yapılmasında belirleyici temel unsur; ulusal ve uluslararası yazında psikolojik sözleşme ihlali ve üretkenlik dışı davranışları bir arada ele alan sınırlı sayıda çalışmanın olmasıdır. Ayrıca söz konusu iki kavramın, kurumsal imaj yönetimi ile ilişkilendirilmemiş olması da çalışmanın yapılmasında etkili olmuştur. Bu bağlamda elde edilen bulguların, yazına ve çalışma yapacak diğer uygulamacılara da katkıda bulunacağı düşünülmektedir.

\section{KURAMSAL ÇERÇEVE}

\subsection{Psikolojik Sözleşme İhlali}

İşletme sahibi ve çalışanların, karşılıklı olarak yerine getirmesi gereken yükümlülükleri içeren, ancak bireysel olarak çalışanların algılarına bağlı olarak değişebilen, iki taraflı yazılı olmayan bir sözleşme şeklinde ifade edilen psikolojik sözleşme kavramı, Argyris (1960) tarafından literatüre kazandırılmış bir kavramdır (Anderson ve Schalk, 1998:638).

Psikolojik sözleşme; kişilerin algıları, beklentileri, inançları, verilen taahhütler ve yerine getirilen yükümlülüklerin toplamını içeren bir olgudur (Guest, 1998:651). Ancak işlevsellik kazanabilmesi için, çalışanların yükümlülükleri yanında, yöneticilerin de yükümlülüklerini yerine getirmeleri gerekmektedir (Rousseau ve Tijoriwala, 1998:680).

Psikolojik sözleşmenin ihlal edilmesi algısı ise, vaat edilenle yerine getirilen sözler arasındaki farklılıklardan kaynaklanmaktadır (Coyle-Shapiro, 2002:930). Başka bir ifadeyle, verilen sözlerin yerine getirilmemesi ya da uyumsuzluk yaşanması durumunda, psikolojik sözleşme ihlalinin olduğu algısı ortaya çıkabilmektedir (Kickul ve Lester, 2001:193; Morrison ve Robinson, 1997:231).

Psikolojik sözleşmenin ihlali; “(1) örgüt tarafından işgörene ilişkin bir taahhüdün terkedilmesi, (2) karşılanmamış taahhüt algılarının ortaya çıkması, (3) taahhüt edilen sözlerle, ortaya çıkan sonuçların karşılaştırılması, (4) sosyal sözleşmenin değerlendirilmesi, (5) sosyal sözleşme ayrıklığının yorumlanması ve (6) psikolojik sözleşmenin ihlal edildiği algısının oluşması" olmak üzere altı aşamada gerçekleşmektedir (Şahin, 2010:93).

Bazı durumlarda işletmeler, çalışanlarına vadettiği yükümlülükleri yerine getirse dahi, çalışanlar vaatlerin yerine getirilmediğini düşünebilmektedir. Biçimsel sözleşmelerin aksine psikolojik sözleşmeler, doğası gereği algısaldır ve bu nedenle de taraflar açısından farklılıklar ortaya çıkabilmektedir (Robinson, 1996:575).

İşletmelerde psikolojik sözleşme ihlalleri genellikle; eğitim ve geliştirme, ödenen ücretler, ödüllendirme, işin niteliği, iş güvenliğgi, değişim yönetimi, geribildirim, sorumluluk ve insan kaynakları gibi konularda ortaya çıkmaktadır (Robinson ve Morrison, 2000:531; Robinson ve Rousseau, 1994:256).

Yurt içi ve yurt dışı yazında psikolojik sözleşme ihlali ile çalışanların tutum ve davranışları arasındaki ilişkiyi açıklamak ve hangi durumlarda ortaya çıktığının tespiti için, daha çok sosyal mübadele teorisinin kullanıldığı görülebilmektedir (Suazo vd., 2005:27). 


\subsection{Psikolojik Sözleşme İhlali ve Üretkenlik Karşıtı Davranışlar}

Üretkenlik karşıtı davranışlar, çalışanların iş performanslarını olumsuz yönde etkileyen ve örgütün verimliliğini azaltacak bilinçli davranışlar olarak tanımlanmaktadır (Lau vd, 2003:73). Ortaya çıkardığı olumsuz etkiler sebebiyle de, son yirmi yıldır literatür araştırmalarına konu olmuştur (Mulki vd., 2006: 1222). Ancak, literatürde üretkenlik karşıtı davranışları tam anlamı ile açıklayıcı bir tanımlama ortaya konulamamıştır (Bruk-Lee ve Spector, 2006:147; Le Roy vd., 2012: 1342). Tanımlara bakıldığında ortak noktanın, söz konusu davranışların, kasıtlı ve meşru menfaatler doğrultusunda gerçekleştirilen olumsuz davranışlar olduğunu söylemek mümkündür (Hafidz, 2012:220).

Genel bir ifade ile üretkenlik karşıtı davranışların, örgütün genel ve özel amaçlarını elde etmeyi engelleyici, örgütsel ilke ve kurallara karşı şiddet gösteren çalışan davranışlarını açıklamak için kullanıldığını söylemek mümkündür (Lau vd, 2003:73). Bu bağlamda üretkenlik karşıtı davranışların, örgütün tüm süreçleri ile çalışanlarına zarar veren, dolayısıyla örgütsel verimliliği azaltan, yasa dışı olmasına rağmen isteğe bağlı olarak gerçekleştirilen davranışlar olduğu söylenebilir (Klotz ve Buckley, 2013:115; Mann vd., 2012:142, Priesemuth vd., 2013:231 Yen ve Teng, 2012: 2; Chirasha ve Mahapa, 2012: 415).

Bir davranışın üretkenlik karşıtı olarak kabul edilmesinde belirleyici olan unsur, davranışın sonucu değil doğrudan doğruya kendisi ve zarar verme potansiyeliyle ilgilidir (Gruys ve Sackett, 2003:30).

Üretkenlik dışı davranışlar her işletmede çeşitli şekillerde ortaya çıkabilmektedir. Bu davranışların hangisinin daha çok ortaya çıkabileceği konusunda ise, insan faktörünün farklılıklar arz etmesinden dolayı tam bir öngörü yapılamamaktadır. Alan yazınlarında yer alan çalışmalardan elde edilen veriler ışı̆̆ında, üretkenlik dışı davranışlar içerisinde yer alabilecek davranış biçimleri Tablo 1'de listelenmiştir.

Tablo 1. Üretkenlik Dışı Davranış Biçimleri

\begin{tabular}{|c|c|}
\hline Örgütsel Boyut & Çalışanlar Boyutu \\
\hline Zarar Verme & Dedikodu \\
\hline Sabotaj & Çatışma \\
\hline Hırsılılı & Misilleme \\
\hline İş Yavaşlatma & İşe Devamsızlık \\
\hline Savurganlık & Duygusal İstismar \\
\hline Bilgiyi Kötüye Kullanma & Ayrımcılık \\
\hline İtaatsizlik & Sözlü ve Fiziksel Saldırılar \\
\hline Ekipmanlara Zarar Verme & Sosyal Baskı ve Mobbing \\
\hline Ürünlere Zarar Verme & Asılsı İddialar Yayma \\
\hline & Irksal Davranma \\
\hline & Yabancılaşma \\
\hline
\end{tabular}

Kaynak: Mount, vd. 2006:594; Everton vd., 2007:118; Tahira vd., 2007:483, Appelbaum vd., 2007:587-588; Seçer ve Seçer, 2007:153; Demirel, 2009:122-123; Wilks, 2011:9; Nair ve Vohra, 2012:26-39.

Psikolojik sözleşme ihlali ve üretkenlik karşıtı davranışları bir arada ele alan çalışmalar incelendiğinde yurt dışı yazında iki, yurt içi yazında ise bir araştırmanın olduğu tespit edilmiştir. 
Bu çalışmalardan bir tanesi Chao, Cheung ve $\mathrm{Wu}$ (2011) tarafından yapılmış olan çalışmadır. $\mathrm{Bu}$ çalışmada psikolojik sözleşme ihlali ile üretkenlik dışı davranışlar arası ilişkiler ve moderatör ara değişken olarak da demografik özelliklerin etkisi incelenmiştir. Çalışmada psikolojik sözleşme ihlali ile üretkenlik dışı davranışlar arasında pozitif yönlü orta düzeyde $(\mathrm{r}=0,24, \mathrm{p}<0,01)$ bir ilişki olduğunun tespit edildiği vurgulanmıştır.

Diğer bir çalışma ise, Jensen, Opland ve Ryan (2010) tarafından yapılan çalışmadır. Bu çalışmada Psikolojik sözleşme ve üretkenlik dışı davranışların neler olduğu irdelenmeye çalışılmıştır. Araştırma bulguları, psikolojik sözleşme ihlali söz konusu olduğunda; sırası ile taciz, sapkın davranışlar, sabotaj ve hırsızlık davranışları gibi üretkenlik dışı davranışların ortaya çıkacağını, bunların da ancak işletme politikaları ile giderilebileceği önerisi getirilmiştir.

Yurt içi alan yazında ise Özdemir ve Demircioğlu (2015) tarafından yapılmış olan çalışmada psikolojik sözleşme ile üretkenlik dışı davranışların alt boyutları arasında düşük ancak anlamlı ilişkiler olduğu $(\mathrm{r}=.01 ; p>.05)$; ifade edilmiştir.

\subsection{Kurumsal İtibar Yönetimi}

İlk defa 1950'li yıllarda kullanılmaya başlanılan kurumsal itibar yönetimi kavramı, özellikle 1990'lardan sonra multidisiplinel bir yaklaşımla kullanılmaya başlanmış ve işletmelerin en önemli başarı ölçütlerinden biri olarak kabul edilen bir olgu haline gelmiştir (Shamma ve Hassan, 2009:326; Jones ve George., 1998:26; Ery1lmaz, 2008:156).

Değişik paydaşların gözündeki imajı ifade eden kurumsal itibar kavramı, kurumun ne olduğu, sorumlulukların nasıl yerine getirildiği ve paydaşların beklentilerinin nasıl karşılandığı gibi sorulara cevap oluşturan algılarla ilgilidir (Argenti ve Druckenmiller, 2004:369; Anca ve Roderick, 2007:234). Bu algılara göre işletmenin genel yapıs1 ve sunduğu ürün ve hizmetler hakkında "iyi veya kötü, zayıf veya güçlü” gibi duygusal bakış açıları ortaya çıkmaktadır. Farklı şekillerde olan bakış açılarının, tarihsel bir birikim ile ortaya çıktığını ifade etmek de mümkündür (Fombrun, 1996:37, Markwick ve Fill, 1997: 398).

Kurumsal itibar olgusu, nicelik olarak ölçümü zor olan inanırlı, güvenirlik, sorumluluk ve doğruluk gibi, birbiri ile iç içe geçmiş konuları kapsamaktadır. Ancak hangi unsurları içerdiğine dair net bir açıklama yapılamamaktadır (Carmeli ve Tishler, 2005:15, Castro vd., 2006:362). Bunun temel nedeni ise, kurumsal itibarın diğer kavramlarla ilişkisinin net olarak belirlenememesinden kaynaklanmaktadır (Tucker ve Melewar, 2005:377).

İşletme hayatında, özellikle etik değerlerin giderek kaybolması, küreselleşme ve tüketici beklentilerinin çeşitlenmesi gibi etmenlerden dolayı kurumlar, diğer varlıkları yönettiği gibi itibarını da yönetmek için itibar yönetimi uygulamalarına yönelmişlerdir (Turner 2004:4, Nakra, 2000:35). Ancak önemle ifade etmek gerekir ki, kurumsal itibar her şeyden önce oldukça kırılgan bir özelliğe sahiptir, bir kere zarar gördü mü onu uzun süre onarmak için yoğun çaba göstermek gerekir (Ewing vd., 1999:122). Bu bağlamda, iyi bir itibara sahip olmak isteyen işletmelerin, kısa dönemli kara odaklanmaktansa, uzun dönemli bir vizyona göre davranmayı tercih etmeleri gerektiği söylenebilir (Tucker ve Melewar, 2005: 387). 
Kurumsal itibarın genel olarak; (1) duygusal çekicilik, (2) ürün ve hizmetler, (3) finansal performans, (4) vizyon ve liderlik, (5) çalışma ortamı ve (6) sosyal sorumluluk olmak üzere altı bileşenden oluştuğu söylenebilir (Fombrun ve Gardberg 2000:14; Devine ve Halpern 2001:42; Dörtok,2004:70). Bu bileşenlerin, rakipler tarafından kopyalanması zor olduğundan dolayı, kurumsal itibarın stratejik bir öneme sahip olduğu ve işletmenin üstün konumunu sürdürmesine olanak sağladığını söylemek mümkündür (Larkin, 2002:2).

Alan yazınında kurumsal itibar ile ilgili olarak yapılan çalışanlara bakıldığında, 1950 ve 1960'lı yıllarda, işletmelerin dışsal çevresine yönelik çalışmalar yapıldı̆̆g, 1970'li yıllarda ise işletme içinde işgörenler ve yöneticilerin bakış açılarının da araştırma kapsamına dahil edildiği görülmektedir (Davies, vd., 2001:113).

Yurt içi ve yurt dışı yazında kurumsal itibar yönetimi konusunda iç çevreye ve dış çevreye yönelik neler yapılması gerektiğine ilişkin önerilerin sıralandığı çalışmalar yapılmasına rağmen, söz konusu kavram ile psikolojik sözleşme ihlali ve üretkenlik dışı davranışları bir arada ele alan çalışmaya rastlanmamıştır. Bu nedenle çalışmamız özellikle kurumsal itibar yönetimin moderatör olabileceği varsayımı ile alanda ilk olma özelliği taşımakta ve yazına katkı sağlayacağı düşünülmektedir.

\section{METEDOLOJI}

\subsection{Araştırmanın Amacı ve Yöntemi}

Araştırmanın amacı; psikolojik sözleşme ihlali ile üretkenlik dışı davranışlar arasındaki ilişkinin tespit edilmesine ve bu ilişkide kurumsal itibar yönetiminin düzenleyici olup olmadığının belirlenmesine yöneliktir.

Araştırma, nicel olarak tasarlanmıştır. Yerli ve yabancı literatür taraması ile elde edilen yazın ile teorik alt yapısı hazırlanmış ve yazılı soru sorma (anket) tekniği ile de veriler elde edilmiştir.

\subsection{Araştırmanın Ana Kütlesi}

Araştırmanın ana kütlesi, yaklaşık 550 personelin kadrolu ve sözleşmeli olarak hizmet verdiği, çelik tencere imalatı yapan bir firmanın tüm çalışanlarıdır. Ana kütleyi temsilen 500 adet anket formu tesadüfi örneklem yöntemi kullanılarak dağıtılmış olup, 272 personelden geri dönüş $(\% 54,4)$ sağlanabilmiştir.

\subsection{Araştırmanın Modeli ve Hipotezler}

Araştırmada kullanılmak üzere iki ana hipotezten yola çıkılmıştır. Bunlar:

- Hipotez ı: Psikolojik sözleşme ihlali ile üretkenlik dışı davranışlar arasında pozitif ilişki vardır.

- Hipotez 2: Kurumsal itibar yönetimi, psikolojik sözleşme ihlali ve üretkenlik karşıtı davranışlar arasındaki ilişkide düzenleyici bir etkiye sahiptir. 
Hipotezlerden yola çıkarak oluşturulan araştırma modeli şekil 1'de görüldüğü gibidir.

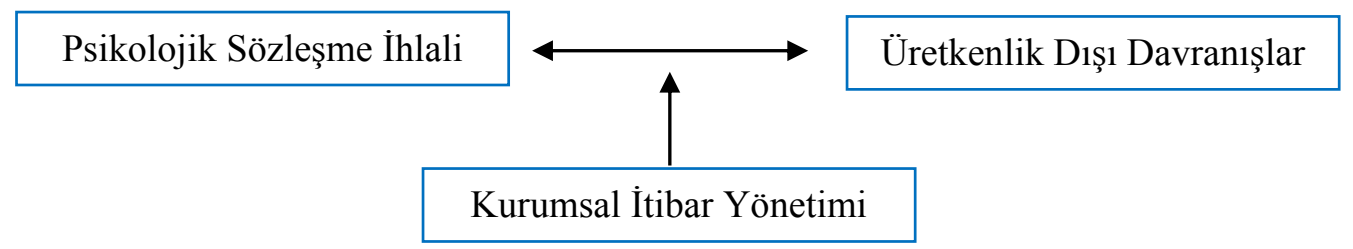

Şekil 1. Araştırmanın Modeli

\subsection{Araştırmada Kullanılan Ölçüm Araçları}

Araştırmada, üç farklı ölçek bir araya getirilerek oluşturulan soru formu kullanılmıştır. Psikolojik sözleşme ihlalini ölçmek için Rousseau (1995) tarafından yapılan çalışmada kullanılan ve Üçok (1995) tarafından Türkçeye uyarlanmış olan Psikolojik sözleşme ihlali ölçeği kullanılmıştır. Söz konusu ölçek 21 önermeden oluşmaktadır.

Üretkenlik dışı davranışları ölçmek için Robinson ve Bennett (1995) tarafından geliştirilen ve Dirican (2013) tarafindan Türkçeye uyarlanmış Üretkenlik dışı davranışlar ölçeği kullanılmıştır. Söz konusu ölçek 19 soru önermesinden oluşmaktadır.

Kurumsal itibar yönetimini ölçmek için ise, Fombrun ve Foss (2001) tarafindan geliştirilip, Yirmibeş (2010) tarafından Türkçeye uyarlanmış olan Kurumsal itibar yönetimi ölçeği kullanılmıştır. Söz konusu bu ölçek ise 25 soru önermesinden oluşmaktadır.

Araştırmada kullanılan ölçekler Likert tipi ölçüm şekliyle (1: Hiç Katılmıyorum, 2: Katılmıyorum, 3: Kararsızım, 4: Katılıyorum, 5: Tamamen Katılıyorum) beşli değerlendirme şeklinde sorulmuştur.

Oluşturulan soru formunda, araştırma yapılacak firmada çalışanların demografik özelliklerini açıklayabilmek adına, "yaş, cinsiyet, medeni durum, eğitim durumu, çalışılan kaçıncı iş yeri olduğu, kıdem ve idari görev" durumlarına ilişkin 7 ayrı soruya yer verilmiştir.

\section{ARAŞTIRMA BULGULARI}

Araştırma kapsamında yer alan kişilerin yaş dağılımları, cinsiyetleri, eğitim durumları, medeni duruları, kaçıncı iş yerinde çalıştıkları ve çalışma sürelerine ilişkin demografik özellikleri tespit edilmek üzere sorulan sorulardan elde edilen bulgular tablo 2'de sunulmuştur.

Elde edilen bulgulara göre araştırmaya katılanların en çok 26-30 $(\% 29,8)$ yaş aralığında yı̆̆ılma gösterdikleri görülmektedir. En düşük yığılma ise 18-25 $(\% 12,5)$ yaş aralığında olduğu tespit edilmiştir. Katılımcıların \%91,1'ini erkekler, \%8,9'unu kadınlar oluşturmaktadır. Eğitim düzeylerine bakıldığında \%31,3'ünün orta öğretim, \%43,8'inin lise, \%8,4'ünün ön lisans, \%13,6'sının lisans ve \%2,9'unun lisansüstü düzeyinde eğitim aldıkları görülmüştür.

Medeni durumda ise, katılımcıların \%71,3'ü evli, \%28,7'si evlidir. Katılımcıların, \%47,8'inin başka bir iş yerinden ayrılarak, araştırma yapılan iş yerinde çalışmaya başladıkları, \%52,2'sinin ise ilk çalışma yerlerinin araştırma yapılan iş yeri olduğu tespit edilmiştir. Kıdem 
durumu incelemesinde ise, \%35,7'sinin 1-4 yıl aralığında, \%38,2'sinin 5-9 yıl aralığında ve son olarak \%26,1'inin 1o y1l ve üzerinde söz konusu işletmede çalıştı̆̆ 1 tespit edilmiştir.

Tablo 2. Demografik Özelliklere İlişkin Bulgular

\begin{tabular}{|c|c|c|c|c|c|}
\hline Yaş Dağılımı & Sayı & $\%$ & Ĕgitim & Sayı & $\%$ \\
\hline $18-25$ & 34 & 12,5 & Orta Öğretim & 85 & 31,3 \\
\hline $26-30$ & 81 & 29,8 & Lise & 119 & 43,8 \\
\hline $31-36$ & 56 & 20,6 & Ön Lisans & 23 & 8,4 \\
\hline $37-42$ & 48 & 17,6 & Lisans & 37 & 13,6 \\
\hline $43+$ & 53 & 19,5 & Lisansüstü & 8 & 2,9 \\
\hline Cinsiyet & Sayı & $\%$ & Medeni Durum & Sayı & $\%$ \\
\hline Kadın & 24 & 8,9 & Evli & 194 & 71,3 \\
\hline Erkek & 248 & 91,1 & Bekar & 78 & 28.7 \\
\hline Kaçıncı İş Yeri & Sayı & $\%$ & Çalışma Süresi & Sayı & \\
\hline Birinci İş Yeri & 142 & 52,2 & $1-4 Y_{11}$ & 97 & 35,7 \\
\hline İkinci İş Yeri & 96 & 35,3 & $5-9 Y_{11}$ & 104 & 38,2 \\
\hline Üçüncü İş Yeri & 23 & 8,5 & $10+Y_{11}$ & 71 & 26,1 \\
\hline $4+$ & 11 & 4,0 & \multicolumn{3}{|c|}{$\mathrm{N}: 272$} \\
\hline
\end{tabular}

\subsection{Tanımlayıcı Faktör Analizleri ve Güvenirlilik Bulguları}

$\mathrm{Bu}$ kısımda kullanılan ölçeklere ilişkin olarak yapılan faktör analizi ve güvenirlilik testi sonuçlarına ayrı ayrı tablolar halinde yer verilmiştir.

Psikolojik sözleşme ihlalini ölçmek için kullanılan ölçeğin yapı geçerliliğini ortaya koymak için, daha önce Üçok (1995) tarafından yapılmış olan çalışma ve literatürdeki genel ayırımlara bağlı kalarak, üç temel boyut (çalışma ortamı, maddi beklentiler ve psikolojik beklentiler) üzerinden ölçüm yapılarak faktör yüklerini belirleyebilmek amacıyla faktör analizi yapılmıştır.

Faktör analizine başlamadan önce verilerin uygunluğuna bakmak için Kaiser Meyer Olkin katsayısı ve Bartlett Sphhericitiy testi hesaplanmıştır. Psikolojik sözleşme ihlaline ilişkin davranışları ölçmek için sorulan soru önermelerinin, kendi içlerindeki güvenirlilik düzeyinin ölçümü için ise Cronbach Alfa skorları incelenmiştir. Elde edilen bulgular ise tablo 3 'te sunulmuştur.

Psikolojik sözleşme ihlalini ölçmek için kullanılan ölçek toplam 21 soru önermesinden oluşmaktadır. Yapılan faktör analizleri sonucunda üç farklı faktör boyutuna ulaşılmış ve yazın doğrultusunda bunlar; "çalışma ortamı", "maddi beklentiler" ve "psikolojik beklentiler" olmak üzere isimlendirilmiştir.

Özgün ölçekte çalışma ortamı boyutunda yer alan 4 nolu soru önermesi, maddi beklentiler boyutunda yer alan 7 ve 9 nolu soru önermeleri ve son olarak psikolojik beklentiler boyutunda yer alan 14, 17, 19 ve 20 nolu soru önermeleri olmak üzere toplam toplam 7 madde, faktör boyutu altında birbirine yakın değer yükleri aldığından veya faktör ağırlığ 0,5 'ten küçük oldukları için analizden çıkartılmıştır. Geri kalan maddelerin özgün ölçekte belirtildiği gibi üç boyuta ayrıldığı ve varyansın da \%59,768'ini açıkladığı belirlenmiştir. 
Tablo 3: Psikolojik Sözleşme İhlali Ölçeğine İlişkin Faktör Analizi ve Güvenirlilik Bulguları

\begin{tabular}{|c|c|c|c|}
\hline Maddeler & Çalışma Ortamı & Maddi Beklentiler & Psikolojik Beklentiler \\
\hline PsyCont 1 & 846 & & \\
\hline PsyCont 2 & 623 & & \\
\hline PsyCont 3 & ,711 & & \\
\hline PsyCont 5 & ,568 & & \\
\hline PsyCont 6 & & ,608 & \\
\hline PsyCont 8 & & ,796 & \\
\hline PsyCont 10 & & ,806 & \\
\hline PsyCont 11 & & ,724 & \\
\hline PsyCont 12 & & & ,748 \\
\hline PsyCont 13 & & & ,726 \\
\hline PsyCont 15 & & &, 818 \\
\hline PsyCont 16 & & & ,749 \\
\hline PsyCont 18 & & & ,601 \\
\hline PsyCont 21 & & & ,793 \\
\hline Açıklanan Varyans & 17,715 & 19,921 & 22,132 \\
\hline Güvenirlilik & ,708 &, 796 &, 872 \\
\hline Toplam & \multicolumn{3}{|c|}{59,768} \\
\hline \multicolumn{2}{|c|}{$\begin{array}{l}\text { Kaiser Meyer Ölçek Güvenirliliği } \\
\text { Bartlett's Küresellik Testi Ki-Kare } \\
\text { Sd } \\
\text { P Değeri }\end{array}$} & $\begin{array}{l}846 \\
564,346 \\
66 \\
, 000\end{array}$ & \\
\hline
\end{tabular}

Tablo 3'te görülebileceği üzere, çalışma ortamına ilişkin boyutların güvenirliliği ,708, maddi beklentiler boyutunun güvenirliliği ,796 ve psikolojik beklentiler boyutunun güvenirliliği ,872 olduğu tespit edilmiş ve sosyal bilimler açısından kabul edilebilir düzeyde oldukları görülmüştür. (KMO=,846, Ki-Kare=564,346, p=0,000).

Psikolojik sözleşme ihlalini ölçmek için kullanılan ölçeğin yapı geçerliliğini ortaya koymak için, daha önce Dirican (2013) tarafindan yapılmış olan çalışma ve literatürdeki genel ayırımlara bağlı kalarak, iki temel boyut (bireysel davranışlar ve örgütsel davranışlar) üzerinden ölçüm yapılarak faktör yüklerini belirleyebilmek amacıyla faktör analizi yapılmıştır.

Faktör analizine başlamadan önce verilerin uygunluğuna bakmak için Kaiser Meyer Olkin katsayısı ve Bartlett Sphhericitiy testi hesaplanmıştır. Üretkenlik dışı davranışları ölçmek için hazırlanmış soru önermelerinin, kendi içlerindeki güvenirlilik düzeyinin ölçümü için ise Cronbach Alfa skorları incelenmiştir. Elde edilen bulgular ise tablo 4'te sunulmuştur. 
Tablo 4: Üretkenlik Dışı Davranışlar Ölçeğine İlişkin Faktör Analizi ve Güvenirlilik Bulguları

\begin{tabular}{|c|c|c|}
\hline Maddeler & Bireysel Davranıșlar & Örgütsel Davranıșlar \\
\hline CWB 1 & ,696 & \\
\hline CWB 2 &, 670 & \\
\hline CWB 4 & ,598 & \\
\hline CWB 5 & ,613 & \\
\hline CWB 6 &, 548 & \\
\hline CWB 7 & 687 & \\
\hline CWB 11 & & ,619 \\
\hline CWB 12 & & ,648 \\
\hline CWB 13 & &, 839 \\
\hline CWB 14 & & ,861 \\
\hline CWB 15 & &, 753 \\
\hline CWB 17 & & 788 \\
\hline CWB 18 & & ,638 \\
\hline Açıklanan Varyans & 24,859 & 28,539 \\
\hline Güvenirlilik & 0,832 &, 813 \\
\hline Toplam & \multicolumn{2}{|c|}{53,398} \\
\hline $\begin{array}{l}\text { Kaiser Meyer Ölçek Güvenirliliği } \\
\text { Bartlett's Küresellik Testi Ki-Kare } \\
\text { Sd } \\
\text { P Değeri }\end{array}$ & \multicolumn{2}{|l|}{$\begin{array}{l}, 863 \\
613,486 \\
82 \\
, 000\end{array}$} \\
\hline
\end{tabular}

Üretkenlik dışı davranışları ölçmek için kullanılan ölçek toplam 19 soru önermesinden oluşmaktadır. Yapılan faktör analizi sonucunda iki farklı faktör boyutuna ulaşılmış ve yazın doğrultusunda bunlar; "bireysel” ve "örgütsel” olmak üzere isimlendirilmiştir.

Özgün ölçekte bireysel boyutta yer alan 3, 8 ve 9 nolu soru önermeleri, örgütsel boyutta yer alan 10,16 ve 19 nolu soru önermeleri olmak üzere toplam 6 madde, faktör boyutu altında birbirine yakın değer yükleri aldığından veya faktör ağırlığı 0,5 'ten küçük oldukları için analizden çıkartılmıştır. Geri kalan maddelerin özgün ölçekte belirtildiği gibi iki boyuta ayrıldığı ve varyansın da \%53,398'ini açıkladığg belirlenmiştir.

Tablo 4'te görülebileceği üzere, bireysel davranışlara ilişkin boyutların güvenirliliği ,832 ve örgütsel davranış boyutunun güvenirliliği ,813 olduğu tespit edilmiş ve sosyal bilimler açısından kabul edilebilir düzeyde oldukları görülmüştür. $(\mathrm{KMO}=, 863$, Ki-Kare $=613,486$, $\mathrm{p}=0,000)$.

Kurumsal itibar yönetimini ölçmek için kullanılan ölçeğin yapı geçerliliğini ortaya koymak için, daha önce Yirmibeş (2010) tarafından yapılmış olan çalışma ve alan yazına bağlı kalarak tek boyut üzerinden ölçüm yapılarak, faktör yüklerini belirleyebilmek amacıyla faktör analizi yapılmıştır.

Faktör analizine başlamadan önce verilerin uygunluğuna bakmak için Kaiser Meyer Olkin katsayısı ve Bartlett Sphhericitiy testi hesaplanmıştır. Kurumsal itibar yönetimini ölçmek için hazırlanmış soru önermelerinin, kendi içlerindeki güvenirlilik düzeyinin ölçümü için ise Cronbach Alfa skorları incelenmiştir. Elde edilen bulgular ise tablo 5'te sunulmuştur. 
Tablo 5: Kurumsal İtibar Yönetimi Ölçeğine İlişkin Faktör Analizi ve Güvenirlilik Bulguları

\begin{tabular}{|l|c|}
\hline Maddeler &, 660 \\
\hline CRM 1 &, 30 \\
\hline CRM 2 &, 641 \\
\hline CRM 3 &, 702 \\
\hline CRM 4 &, 577 \\
\hline CRM 5 &, 672 \\
\hline CRM 6 &, 766 \\
\hline CRM 7 &, 545 \\
\hline CRM 8 &, 748 \\
\hline CRM 11 &, 816 \\
\hline CRM 12 &, 778 \\
\hline CRM 16 &, 793 \\
\hline CRM 17 &, 601 \\
\hline CRM 18 &, 574 \\
\hline CRM 19 &, 596 \\
\hline CRM 20 &, 636 \\
\hline CRM 21 &, 732 \\
\hline CRM 22 &, 661 \\
\hline CRM 23 &, 618 \\
\hline CRM 24 &, 556 \\
\hline CRM 25 & 52,431 \\
\hline Açılanan Varyans & \\
\hline Güvenirlilik &, 742 \\
\hline Kaiser-Meyer-Olkin & 591,862 \\
Bartlett's Küresellik Testi Ki-Kare & \\
\hline Sd & \\
\hline P Değeri &, 800 \\
\hline
\end{tabular}

Üretkenlik dışı davranışları ölçmek için kullanılan ölçek toplam 25 soru önermesinden oluşmaktadır. Yapılan faktör analizi sonucunda maddeler tek faktör boyutunda toplanmış ve varyansın \%52,431'ini açıkladığı belirlenmiştir. Ölçekte yer alan 9, 10, 13, 14 ve 15 nolu soru önermeleri faktör ağırlığ 10,5 ’ten küçük oldukları için analizden çıkartılmıştır.

Tablo 5'ten görülebileceği üzere, kurumsal itibar yönetimi ölçeğinin güvenirliliğinin ,893 olduğu tespit edilmiş ve sosyal bilimler açısından kabul edilebilir düzeyde olduğu görülmüştür. $(\mathrm{KMO}=, 742$, Ki-Kare $=591,862, \mathrm{p}=0,000)$.

\subsection{Değişkenlere İliş̧kin Tanımlayıcı Bulgular}

Değişkenlere ilişkin tanımlayıcı istatistik bulguları tablo 6'da yer almaktadır. Bulgulara göre, psikolojik sözleşme ihlali $(X=3,61, S=.59)$, üretkenlik dışı davranışlar $(X=4,63, S=.69)$ ve kurumsal itibar yönetimi $(X=3,86, S=.72)$ ortalamaları bulunmuştur. Tüm değerler ortalamanın üstünde olup, elde edilebilecek maksimum puanlar dikkate alındığında en yüksek ortalamanın kurumsal itibar yönetimine at olduğu, bunu üretim dışı davranışların izlediği, en düşük ortalamanın ise psikolojik sözleşme ihlaline ait olduğu görülmektedir. 


\begin{tabular}{|l|c|c|c|c|c|}
\hline & N & Min. & Max. & X & S \\
\hline Psikolojik Sözleşme İhlali (PCV) & 272 & 1,98 & 5,00 & 3,6106 &, 50817 \\
\hline Üretkenlik Dış1 Davranışlar (CWB) & 272 & 233 & 5,00 & 4,6380 &, 69713 \\
\hline Kurumsal İtibar Yönetimi (CRM) & 272 & 1,00 & 5,00 & 3,8670 &, 72843 \\
\hline
\end{tabular}

\subsection{Değişkenler Arasındaki İlişkilere İlişkin Bulgular}

Değişkenler arası ilişkiler incelenmek için yapılan korelasyon analizi bulguları tablo 7'de sunulmuştur.

Tablo 7: Değişkenler Arasındaki İlişskilere İlişkin Korelasyon Bulguları

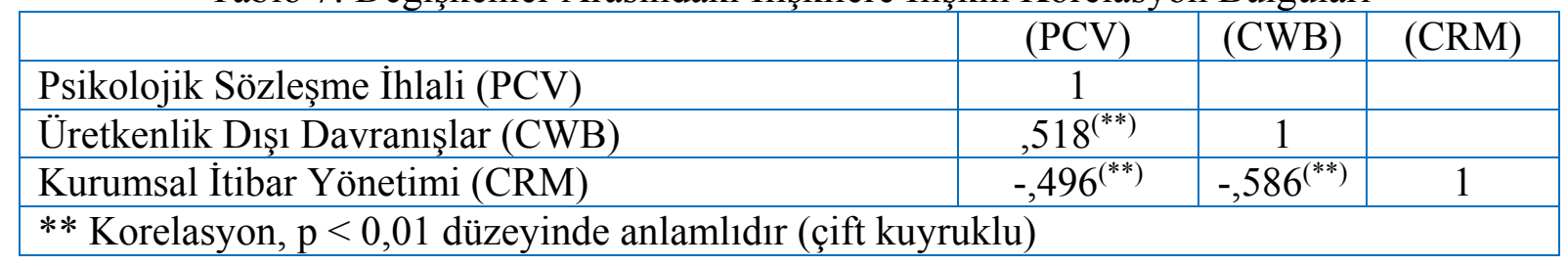

Tablo 7'den de görüleceği üzere elde edilen bulgulara göre, psikolojik sözleşme ihlali ile üretkenlik dışı davranışlar $(\mathrm{r}=, 518, \mathrm{p}<0,01)$ pozitif yönde orta düzeyde ve anlamlı şekilde ilişkilidirler.

Psikolojik sözleşme ihlali ile kurumsal itibar yönetimi $(r=-, 496, p<0,01)$ negatif yönde orta düzeyde ve anlamlı şekilde ilişkilidirler.

Üretkenlik dışı davranışlar ile kurumsal itibar yönetimi $(-, 586, p<0,01)$ negatif yönde orta düzeyde ve anlamlı şekilde ilişkilidirler.

Başka bir ifade ile, psikolojik sözleşme ihlali algısında artış görüldüğü zaman üretkenlik dışı davranışlarda da artış görüleceğini söylemek mümkündür. Tabloda yer alan sonuçlara göre değişkenlere ait en güçlü ilişkinin ise, üretkenlik dışı davranışlar ile kurumsal itibar yönetimi arasında olduğu görülmektedir.

$\mathrm{Bu}$ sonuçlar 1şı̆̆ından "Psikolojik sözleşme ihlali ile üretkenlik dışı davranışlar arasında pozitif ilişki vardır” şeklindeki hipotez a kabul edilmiştir.

\subsection{Kurumsal İtibar Yönetiminin, Psikolojik Sözleşme İhlali ile Üretkenlik Karşıtı Davranışlar İlişkisinde Düzenleyici Etkisine İlişkin Çoklu Regresyon Analizi Bulguları}

Araştırmanın ana hipotezi olan kurumsal itibar yönetiminin, psikolojik sözleşme ihlali ve üretkenlik dışı davranışlarda düzenleyici rolünü sorgulamak amacıyla çoklu regresyon analizi yapılmıştır. Bulgular tablo 8'de yer almaktadır. 


\begin{tabular}{|c|c|c|c|c|c|}
\hline \multirow[t]{2}{*}{ Model } & \multicolumn{4}{|c|}{ Coefficient } & \multirow[b]{2}{*}{$\mathrm{p}$} \\
\hline & Beta $(\beta)$ & s.hata & Beta $(\beta)$ & $\mathbf{t}$ & \\
\hline 1 (fixed) & 2,262 & ,256 & \multirow[t]{2}{*}{,583 } & 8,203 & ,000 \\
\hline CWB &,- 578 &, 063 & & $-8,351$ &, 000 \\
\hline 2 (fixed) & 1,684 & ,283 & \multirow{3}{*}{$\begin{array}{l}, 425 \\
, 319\end{array}$} & 4,872 &, 000 \\
\hline CWB &,- 423 & ,072 & & $-4,970$ &, 000 \\
\hline and CRM &, 381 &, 086 & & 3,428 &, 000 \\
\hline 3 (fixed) & 1,562 & 275 & \multirow{4}{*}{$\begin{array}{l}, 412 \\
-, 335 \\
, 247\end{array}$} & 4,561 &, 000 \\
\hline CWB & -406 & ,069 & & 4,991 &, 000 \\
\hline CRM & ,394 &, 083 & & $-3,776$ &, 000 \\
\hline Interaction & ,362 & ,092 & & 3,970 &, 000 \\
\hline \multicolumn{6}{|c|}{$\begin{array}{l}\text { Bağımlı Değişken: Üretkenlik Dışı Davranışlar } \\
\mathrm{R}=583 \mathrm{R}^{2}=, 258 \mathrm{~F}=75,854, \mathrm{p}=, 000 \\
\mathrm{R}=641 \mathrm{R}^{2}=, 314 \mathrm{~F}=24,157, \mathrm{p}=, 000 \\
\mathrm{R}=689 \mathrm{R}^{2}=, 358 \mathrm{~F}=18,348, \mathrm{p}=, 000\end{array}$} \\
\hline
\end{tabular}

Bulgular incelendiğinde; ikinci aşamada Kurumsal itibar yönetiminin (CRM) modele eklenmesi ile $\mathrm{R}^{2}$ 'de $(, 056)$ değişim ortaya çıkmakta ve kurumsal itibar yönetimi için elde edilen kısmı $\mathrm{F}$ değeri $(\mathrm{F}=24,157 \mathrm{p} \leq, 001)$ değişimin istatistiksel olarak anlamlı olduğunu işaret etmektedir. Üçüncü aşamada etkileşim değişkenlerinin denkleme girmesi ile $\mathrm{R}^{2}$ de $(, 044)$ artış olmaktadır ve bu değişim de $(\mathrm{F}=18,348 \mathrm{p} \leq, 001)$ istatistiksel olarak anlamlıdır.

Bu bulgulara göre; kurumsal itibar yönetiminin üretkenlik dışı davranışlar üzerinde bağımsız bir değişken olarak etkili olduğunu söylemek mümkündür. Ayrıca kurumsal itibar yönetimi, psikolojik sözleşme ihlali ve üretkenlik dışı davranışlar üzerinde kısmı değişken olarak düzenleyici olduğu ifade edilebilir.

Elde edilen veriler 1şı̆̆ında kurumsal itibar yönetimine ilişkin yapılan faaliyetler, psikolojik sözleşme ihlalini ve üretkenlik dışı davranışların azalmasına neden olduğu söylenebilir. Aynı zamanda tam tersi bir durumun düşünüldüğünde de psikolojik sözleşme ihlali ve üretkenlik dışı davranışların olduğu zamanlarda kurumsal itibar yönetimini de zarar görebileceğini ifade etmek mümkünüdür.

Çoklu regresyon testi sonuçları dikkate alındığında "kurumsal itibar yönetimi, psikolojik sözleşme ihlali ve üretkenlik karşıtı davranışlar arasındaki ilişkide düzenleyici bir etkiye sahiptir" şeklindeki $\mathrm{H}_{2}$ hipotezimize ait önerme kabul edilmiştir.

\section{SONUÇ ve ÖNERILLER}

İnsan faktörünün olduğu her yerde algısal farklılıkların olması olağan bir durumdur. Geçmiş yaşantı ve deneyimler, demografik özelliklerdeki farklılıklar, yöneticilerin tutum ve davranışları gibi bir çok unsur algı farlılıklarının ortaya çıkmasında ana etmen olabilmektedir. Algılamaların olumsuz şekilde ortaya çıkması ise, işletme hayatına zarar verebilmektedir. Psikolojik sözleşme ihlali ve üretkenlik dışı davranışlar ise karşılaşılabilecek olumsuz algılar ile alakalı kavramlardır. Bu algıların olumlu hale getirilmesinde ise, kurumsal itibar yönetimi uygulamalarının kullanılabileceği düşünülmüsstür. 
$\mathrm{Bu}$ çalışmanın amacı, yazında bazı araştırmalarda test edilen psikolojik sözleşme ihlali ve üretkenlik dışı davranışlar arasındaki pozitif ve anlamlı ilişkinin, kurumsal itibar yönetiminin etkisi ile düşürülebileceği varsayımını test etmektir. Dolayısıyla, kurumsal itibar yönetimi uygulamaları ile psikolojik sözleşme ihlallerinin olduğu algısının ve akabinde ortaya çıkabilecek üretkenlik dışı davranışların azaltılabileceği yönünde önemli bir belirleyici faktör olacağı öngörülmüştür.

Araştırmanın bir bölümünü oluşturan "psikolojik sözleşme ihlali ve üretkenlik dışı davranışlar" arasındaki ilişkiyi ele alan yurt dışında 2, yurt içinde ise 1 çalışma yapılmıştır. Elde edilen bulgular söz konusu çalışmaların bulgularını destekler niteliktedir. Söz konusu iki kavram arasında pozitif yönde ve orta düzeyde anlamlı bir ilişki tespit edilmiştir. Araştırmamızın sonuçlarının yurt içi ve yurt dışı çalışmalar ile örtüşmesi ve bu konuda yapılan çalışmanın çok az denecek kadar sınırlı sayıda kalması sebebiyle, iki olgunun etkileşimsel bazda irdelenmesi dikkate değerdir. Çünkü psikolojik sözleşme ihlallerinin görüldügü ve bu konuda algıların oluştuğu işletmelerde, üretkenlik davranışlarının artacağına yönelik işaretler söz konusudur.

Araştırmamızın esas amacını oluşturan kurumsal itibar yönetimin düzenleyici etkisine yönelik çalışma ise daha önce yapılmamıştır. Elde edilen bulgular ile kurumsal itibar yönetiminin düzenleyici etkisinin olduğu sonucuna ulaşılmıştır. Bu sonuca göre, psikolojik sözleşme ihlali ve üretkenlik dışı davranışlar arasındaki ilişkide, kurumsal itibar yönetimi uygulamalarının firmalara yarar sağlayacağı düşünülebilir. Araştırmamızda irdelenen söz konusu üç kavramın da insan faktörü ile ilgili olduğu ve algılamalar yoluyla ortaya çıkan unsurlar olduğu dikkate alındığında, olumsuz algılamaların giderilmesinde kurumsal itibar yönetiminin kullanılabileceğini söylemek mümkündür.

Elde edilen bulgular ve yazın dikkate alındığında, uygulamaya yönelik olarak değerlendirildiğinde üç ayrı unsurun dikkate alınması gerektiği söylenebilir. Bunlardan ilki, psikolojik sözleşme ihlallerinin ortaya çıkmasında çalışan ve yöneticilerin algılarının önemli olduğunun mutlak düzeyde dikkate alınması gerekliliğidir. Algılamaların olumsuz hal almaması için de iletişim unsuruna önem verilmesi gerekmektedir. Etkili bir iletişimin sağlanması ile ortaya çıkabilecek olumsuz düşüncelerin önüne geçilebilecektir. Aksi halde psikolojik sözleşme ihlaline yönelik algılar nedeniyle, işletmelerin karşı karşıya kalacağ olumsuz durumların bertaraf edilmesi pek mümkün görülmemektedir.

İkinci önemli unsur ise üretkenlik karşıtı davranışların ortaya çıkmasına neden olan etmenlerin, örgütsel ve çalışanlar boyutlarında ayrı ayrı ele alınması gerekmektedir. Öncelikli olarak örgütsel boyutta yer alabilecek unsurların dikkate alınması sonrasında ise çalışan boyutuna müdahale edilmesi gerekmektedir. İşletmenin tüm süreçleri belirli zaman aralıkları ile kontrol edilmeli ve verimliliği azaltan etmenlerin giderilmesine yönelik çalışmaların yapılması yöneticilerin görevi haline getirilmelidir.

Son olarak kurumsal itibar yönetimi ile öncelik iç müşterilere yani çalışanlara verilmelidir. Özellikle çalışma ortamına yönelik düzenleyici ve geliştirici çalışmaların yapılması, çalışanların memnuniyet derecesini arttırabileceğinden dolayı, kurumsal itibar yönetimi uygulamalarında başarılı sonuçlar elde edilme olasılığının kuvvetleneceği unutulmamalıdır.

$\mathrm{Bu}$ çalışma çelik tencere sektöründe tek bir işletmenin çalışanları üzerinde yapılmış olmasından dolayı, araştırmanın farklı sektörlerde tekrar edilmesi, elde edilen bulguların 
destelenmesi ve genele yayılması açısından önemlidir. Kurumsal itibar yönetiminin çalışanlar ve örgütsel düzeyde boyutlandırılması ile yapılabilecek bir çalışma alana katkı sağlayabilecektir.

\section{REFERENCES}

- ANCA, C.E. ve RODERICK, B. (2007). "The Influence of Brand Image and Company Reputation Where Manufacturers Market to Small Firms: A Costomer Value Perspective", Industrial Marketing Management Journal, 36(2):230-240.

- ANDERSON, N. ve SCHALK, R. (1998). "The Psychological Contract in Retrospect and Prospect", Journal of Organizational Behavior, 19(1):637-647.

- APPELBAUM, S.H.; IACONI, G.D. ve MATOUSEK, A. (2007). "Positive and Negative Deviant Workplace Behaviors: Causes, Impacts and Solutions", Corporate Governance, 7(5):586-598.

- ARGENTI, P.A. ve DRUCKENMILLER, B. (2004). "Reputation and the Corporation Brand", Corporate Reputation Review, 6(4):368-274.

- BAYBORA, D. (2011). "Kurumsal İtibar ve Çalışanlar", Kurumsal İtibar ve Paradigmalar (Editör:Şakar, N.), Beta Yayınevi, İstanbul.

- BRUK-LEE, V. ve SPECTOR, P.E. (2006). "The Social Stressors-Counterproductive Work Behaviors Link: Are Conflicts With Supervisors and Coworkers the Ame?", Journal of Occupational Health Psychology, 11(2):145-156.

- CARMEli, A. ve TISHLER, A. (2005). "Perceived Organizational Reputation and Organizational Performance: An Empirical Investigation of Industrial Enterprises", Corporate Reputation Review, 8(1):13-30.

- CASTRO, De, G.M., LOPEZ, J.E.N. ve SAEZ, P.L. (2006). "Business and Social Reputation Exploring the Concept and Main Dimensions of Corporate Reputation", Journal of Business Ethics, 63:361-370.

- CHAO, J. M., CHEUNG, F. Y., ve WU, A. M. (2011). "Psychological Contract Breach and Counterproductive Workplace Behaviors: Testing Moderating Effect of Attribution Style and Power Distance", The International Journal of Human Resource Management, 22(4): 763-777.

- CHIRASHA, V. ve MAHAPA, M. (2012). "An Analysis of the Causes and Impact of Deviant Behaviour in the Workplace, The Case of Secretaries in State Universities", Journal of Emerging Trends in Economics and Management Sciences, 3(5):415-421.

- COYLE-SHAPIRO J. (2002). "A Psychological Contract Perspective on Organizational Citizenship Behaviour", Journal of Organizational Behaviour, 23(8):927-946.

- DAVIES, G.R; CHUN, R.; SILVA, R.V. ve ROPER, S. (2001). "The Personification Metaphor as a Measurement Approach for Corporate Reputation", Corporate Reputation Review, 5(2):113-127.

- DEMİREL, Y. (2009). "Örgütsel Bağlılık ve Üretkenlik Karşıtı Davranışlar Arasındaki İlişkiye Kavramsal Yaklaşım”, İstanbul Ticaret Üniversitesi Sosyal Bilimler Dergisi, 8(15):115-132.

- DİRİCAN, A.H. (2013). "Duygusal Zekanın Örgütsel Vatandaşlık davranışı ve Üretkenlik Karşıtı Davranışlar Üzerine Etkisi” (Yüksek Lisans Tezi), Gebze İleri Teknoloji Enstitüsü Sosyal Bilimler Enstitüsü, Gebze.

- DÖRTOK, A. (2004). Kurumsal İtibarınızdan Kaç Sıfır Atabilirsiniz?, Rota Yayınları, İstanbul. 
- ERYILMAZ, M.E. (2008). "Örgüt İtibar Kavramı ve Yönetimi ile İlgili Bazı Sorunlar", Anadolu Üniversitesi Sosyal Bilimler Dergisi, 8(1):155-174.

- EVERTON, W.J.; JOLTON, J.A. ve MASTRANGELO, P.M. (2007). "Be Nice and Fair or Else: Understanding Reasons for Employees Deviant Behaviors", Journal of Management Development, 26(2):117-131.

- EWING, T.; CARAUNANA, M.A ve LOY, E.R. (1999). "Corporate Reputation and Perceived Risk In Professional Engineering Services", Corporate Communications: An International Journal, 4(3):121-128.

- FOMBRUN, C.J. (1996). Reputation: Realizing Value From The Corporate Image, Harvard Business School Press, Boston, Massachusetts.

- FOMBRUN, C.J. ve GARDBERG, N. (2000). "Who's Tops in Corporate Reputation?", Corporate Reputation Review, 3(1):13-17.

- FOMBRUN, C.J. ve FOSS C.B. (2001), The Reputation Quotient, Part:1 Developing a Reputation Quotient, The Gague Delahaye Medialink's Newsletter of Worldwide Communications Research, 14(3).

- GOTSI, M. ve WILSON, A. (2001). "Corporate Reputation: Seeking a Defination", Corporate Communication, 6(1):24-30.

- GUEST, D.E. (1998). "Is The Psychological Contract Worth Taking Seriously?", Journal of Organizational Behavior, 19(1):649-664.

- GRUYS M.L. ve SACKETT, P.R. (2003). "Investigating the Dimentionality of Counterproductive Work Behavior", International Journal of Selection and Assessment, 11(1):30-42.

- HAFIDZ, S.W.M. (2012). "Individual Differences as Antecedents of Counterproductive Work Behaviour", Asian Social Science, 8(3):220-226.

- JONES, G.R. ve GEORGE, J.M. (1998). "The Experience And Evolution Of Trust: Implications For Cooperation And Teamwork", Academy of Management Review, 23(3):531-546.

- JENSEN, J. M., OPLAND, R. A., ve RYAN, A. M. (2010). "Psychological Contracts and Counterproductive Work Behaviors: Employee Responses to Transactional and Relational Breach", Journal of Business and Psychology, 25(4):555-568.

- KICKUL, J. ve LESTER, S.W. (2001). "Broken Promises: Equity Sensitivity as a Moderator Between Psychological Contract Breach and Employee Attitudes and Behavior", Journal of Business and Psychology, 16(2):191-217.

- KLOTZ, A.C. ve BUCKLEY, M.R. (2013). "A Historical Perspective of Counterproductive Work Behavior Targeting the Organization", Journal of Management History, 19(1):114 -132.

- LARKIN, J. (2002). Strategic Reputation Risk Management. Palgrave Macmillan.

- LAU, V.C.S.; AU, W.T. ve HO, J.M.C. (2003). "A Qualitative and Quantitative Review of Antecedents of Counterproductive Behavior in Organizations", Journal of Business and Psychology, 18(1):73-100.

- LE ROY, J.; BASTOUNIS, M. ve MINIBAS-POUSSARD, J. (2012). "Interactional Justice and Counterproductive Work Behaviors: The Mediating Role of Negative Emotions", Social Behavior and Personality, 40(8):1341-1355.

- MANN, S.L.; BUDWORTH, M. ve ISMAILA, A.S. (2012). "Ratings of Counterproductive Performance: the Effect of Source and Rater Behavior", International Journal of Productivity and Performance Management, 61(2):142-156.

- MARKWICK, N. ve FILL, C. (1997). "Towards A Framework for Managing Corporate Identity", European Journal of Marketing, 31(5/6):396-409. 
- MORRISON, E.W. ve ROBINSON, S.L. (1997). "When Employees Feel Betrayed: A Model of How Psychological Contract Violation Develops", Academy of Management Review, 22(1):226-256.

- $\quad$ MOUNT, M.; ILIES, R. ve JOHNSON, E. (2006). "Relationship of Personality Traits and Counterproductive Work Behaviors: The Mediating Effects of Job Satisfaction", Personnel Psychology, 59(3):591-622.

- MULKI, J.P.; JARAMILlO, F. ve LOCANDER, W.B. (2006). "Emotional Exhaustion and Organizational Deviance: Can the Right Job and a Leader's Style Make a Difference?", Journal of Business Research, 59(12):1222-1230.

- NAIR, N. ve VOHRA, N. (2012). "The Concept of Alienation: Towards Conceptual Clarity", International Journal of Organizational Analysis, 20(1):25-50.

- NAKRA, P. (2000). "Corporate Reputation Management: CRM With a Strategic Twist", Public Relations Quarterly, 45(2):35-42.

- ÖZDEMIR, M. ve DEMIRCIOĞLU, E. (2015). "The Relationship Between Counterproductive Work Behaviours And Psychological Contracts In Public High Schools", Çukurova Üniversitesi Eğitim Fakültesi Dergisi, 45(1):41-60.

- PRIESEMUTH, M.; ARNAUD, A. ve SCHMINKE, M. (2013). "Bad Behavior in Groups: The Impact of Overall Justice Climate and Functional Dependence on Counterproductive Work Behavior in Work Units", Group \& Organization Management, 38(2):230-257.

- ROBINSON S.L. (1996). "Trust and Breach of the Psychological Contract", Administrative Science Quarterly, 41(4):574-599.

- ROBINSON S.L. ve MORRISON, E.W. (2000). "The Development of Psychological Contract Breach and Violation: A Longitudinal Study", Journal of Organizational Behavior, 21:525-546.

- ROBINSON, S.L. ve ROUSSEAU, D.M. (1994). "Violating the Psychological Contract: Not the Exception But the Norm", Journal of Organizational Behavior, 15(3):245-259.

- ROBINSON, S. L., ve BENNETT, R. J. (1995). "A Typology of Deviant Workplace Behaviors: A Multidimensional Scaling Study", Academy of Management Journal, 38(2):555-572.

- ROUSSEAU, M.D. ve TIJORIWALA, A.S. (1998). "Assessing Psychological Contracts: Issues, Alternatives and Measures", Journal of Organizational Behavior, 19(1):679-695.

- ROUSSEAU, D. M. (1995). Psychological Contracts in Organizations; Understanding Written and Unwritten Agreements. Thousand Oaks: Sage Publications Inc. California.

- SAYLI, H. ve UĞURLU, Ö.Y. (2007). 'Kurumsal İtibar ve Yönetsel Etik İlişkisinin Analizine Yönelik Bir Değerlendirme', Süleyman Demirel Üniversitesi İktisadi ve İdari Bilimler Fakültesi Dergisi, 12(3):75-96.

- SHAMMA, H.M ve HASSAN, S.S. (2009). "Customer and Non-Customer Perspectives for Examining Corporate Reputation", Journal of Product \& Brand Management, 18(5):326-337.

- SUAZO, M.M.; TURNLEY W.H. ve MAI R.R. (2005). "The Role of Perceived Violation in Determining Employees' Reactions to Psychological Contract Breach", Journal of Leadership \& Organizational Studies, 12(1):24-36.

- SEÇER, H.Ş. ve ŞEÇER, B. (2007). "Örgütlerde Üretkenlik Karşıtı İş Davranışları: Belirleyicileri ve Önlenmesi”, TİSK Akademi, 2007(II):147-175. 
- ŞAHIN Dil, M. (2010). “Örgütsel Davranışta Güncel Konular”, (Editör: N.Derya Ergun Özler), Ekin Yayınevi, Bursa.

- TAHIRA, M.P.; STEWART, S.M; GRUYS, M.L. ve TIERNEY, B.W. (2007). "Productivity, Counterproductivity and Creativity: The Ups and Downs of Job Insecurity", Journal of Occupational and Organizational Psychology, 80(3):479-497.

- TUCKER, L. ve MELEWAR, T.C. (2005). "Corporate Reputation and Crisis Management: The Threat and Manageability of Anti-Corporatism", Corporate Reputation Review, 7(4):377-387.

- ÜÇOK, D.I. (2012). "Sinik Tutum ve psikolojik Sözleşme İhlali Algısının Tükenmişlik Üzerindeki Etkisi”, (Yüksek Lisans Tezi), Marmara Üniversitesi Sosyal Bilimler Enstitüsü, İstanbul.

- YEN, C. ve TENG, H. (2012). "The Effect of Centralization on Organizational Citizenship Behavior and Deviant Workplace Behavior in the Hospitality Industry", Tourism Management, 36:401-410.

- YİRMİBEŞ, S. (2010), "Kurumsal İtibar Yönetimi ve Kamuya Bağlı Bir Kurumda Kurumsal İtibarın Ölçülmesi Üzerine Bir Araştırma”, (Yüksek Lisans Tezi), Dokuz Eylül Üniversitesi Sosyal Bilimler Enstitüsü, İzmir.

- WILKS, D.C. (2011). "Attitudes Towards Unethical Behaviours in Organizational Settings: An Empirical Study”, Ethics in Progress Quarterly, 2(2):9-22. 